\title{
Nerocila species (Crustacea, Isopoda, Cymothoidae) from Indian marine fishes
}

\author{
Jean-Paul Trilles • Ganapathy Rameshkumar • \\ Samuthirapandian Ravichandran
}

Received: 18 September 2012 /Accepted: 17 December 2012 /Published online: 17 January 2013

(C) The Author(s) 2013. This article is published with open access at Springerlink.com

\begin{abstract}
Eleven Nerocila species are recorded from 22 marine fishes belonging to 15 families. Three, Nerocila arres, Nerocila depressa, and Nerocila loveni, are new for the Indian fauna. $N$. arres and Nerocila sigani, previously synonymized, are redescribed and their individuality is restored. Nerocila exocoeti, until now inadequately identified, is described and distinctly characterized. A neotype is designated. New hosts were identified for $N$. depressa, $N$. loveni, Nerocila phaiopleura, Nerocila serra, and Nerocila sundaica. Host-parasite relationships were considered. The parasitologic indexes were calculated. The site of attachment of the parasites on their hosts was also observed. A checklist of the nominal Nerocila species until now reported from Indian marine fishes was compiled.
\end{abstract}

\section{Introduction}

Many fish species are parasitized by Cymothoid isopods. They are found from various parts of the fish, on the skin, on the fins, in the buccal or branchial cavities, sometimes in a pouch. Some are highly host specific, even in the manca stage (Trilles 1964; Tsai et al. 1999). However, several species show a poor host specificity and the mancae may attach and feed on optional intermediate hosts belonging to different fish families (Sarusic

Electronic supplementary material The online version of this article (doi:10.1007/s00436-012-3263-5) contains supplementary material, which is available to authorized users.

J.-P. Trilles

UMR 5119 (CNRS-UM2- IRD-UM1-IFREMER), Equipe

Adaptation Ecophysiologique et Ontogenèse,

Université Montpellier 2, CC. 092, Place E. Bataillon,

34095 Montpellier Cedex 05, France

G. Rameshkumar $(\bowtie) \cdot$ S. Ravichandran

Centre of Advanced Study in Marine Biology, Faculty of Marine

Sciences, Annamalai University, Parangipettai 608 502,

Tamil Nadu, India

e-mail: grkumarcas@gmail.com
1999) and sometimes even on several other organisms (Trilles and Öktener 2004; Wunderlich et al. 2011).

Nerocila is a large genus of the family Cymothoidae including at least 65 species living attached on the skin or on the fins of fishes. As already reported by Trilles (1972, 1979), Williams and Williams (1980, 1981), and Bruce (1987a, b), several species are morphologically highly variable and their identification is often difficult. The variability was particularly studied in Nerocila armata and Nerocila orbignyi (Monod 1931), Nerocila excisa (Trilles 1972), Nerocila sundaica (Bowman 1978), Nerocila acuminata (Brusca 1981), Nerocila arres, and Nerocila kisra (Bowman and Tareen 1983), and N. orbignyi, Nerocila monodi, and Nerocila phaiopleura (Bruce 1987a).

Until now few studies were performed on parasites collected from Indian marine fishes (Pillai 1954, 1964; Ravichandran et al. 2010; Rameshkumar et al. 2011, 2012a, b; Trilles et al. 2011). Nevertheless, 17 nominal species belonging to the genus Nerocila were so far reported from India. However, several of these reports, often published in local journals not easily accessible, contain misidentifications and descriptions that are of doubtful validity. Thus, a more accurate study of the Indian Nerocila species is necessary (Trilles et al. 2011).

In the present survey, 11 species were collected. Parasitologic indexes, host species, and geographic distribution are reported for each. A taxonomic study is performed for $N$. arres, Nerocila exocoeti, and Nerocila sigani, poorly known or inadequately identified. A comprehensive summary of the nominal Nerocila species until now recorded from India is also provided.

\section{Materials and methods}

One thousand six hundred forty-six specimens belonging to 22 fish species were directly collected from the trawlers 
landed at the Tamil Nadu coasts in South India (Fig. 1 and Table 1) from April 2009 to December 2011. Samplings were performed twice monthly. Isopods were removed alive from the host and immediately placed into $70 \%$ ethanol. The sampling date, locality, host fish, and site of attachment on the host fish were recorded. Mouthparts and appendages were carefully dissected using dissecting needles and forceps. Drawings were made with the aid of a camera lucida. The total length of isopods was measured and recorded in millimeters. The overall prevalence (number of infested hosts/number of examined hosts $\times 100 \%$ ) and intensity (total number of parasites/number of infested hosts) were calculated according to Margolis et al. (1982) and Bush et al. (1997) as well as the mean prevalence and intensity for each parasite-host association. The parasites were identified according to Pillai (1954), Trilles, (1975; 1979), Bowman (1978), Bowman and Tareen (1983), Bruce (1987a), Bruce and Harrison-Nelson 1988), and Rameshkumar et al. (2011). Voucher specimens were deposited at the Annamalai University, India (collection Ravichandran) and at the National Museum of Natural History, Paris, France (Appendix). Host nomenclature and fish taxonomy are according to Fish Base (Froese and Pauly 2011). A checklist of the Nerocila nominal species already reported from Indian marine fishes, updated with our new reports, was compiled (Electronic supplementary material).

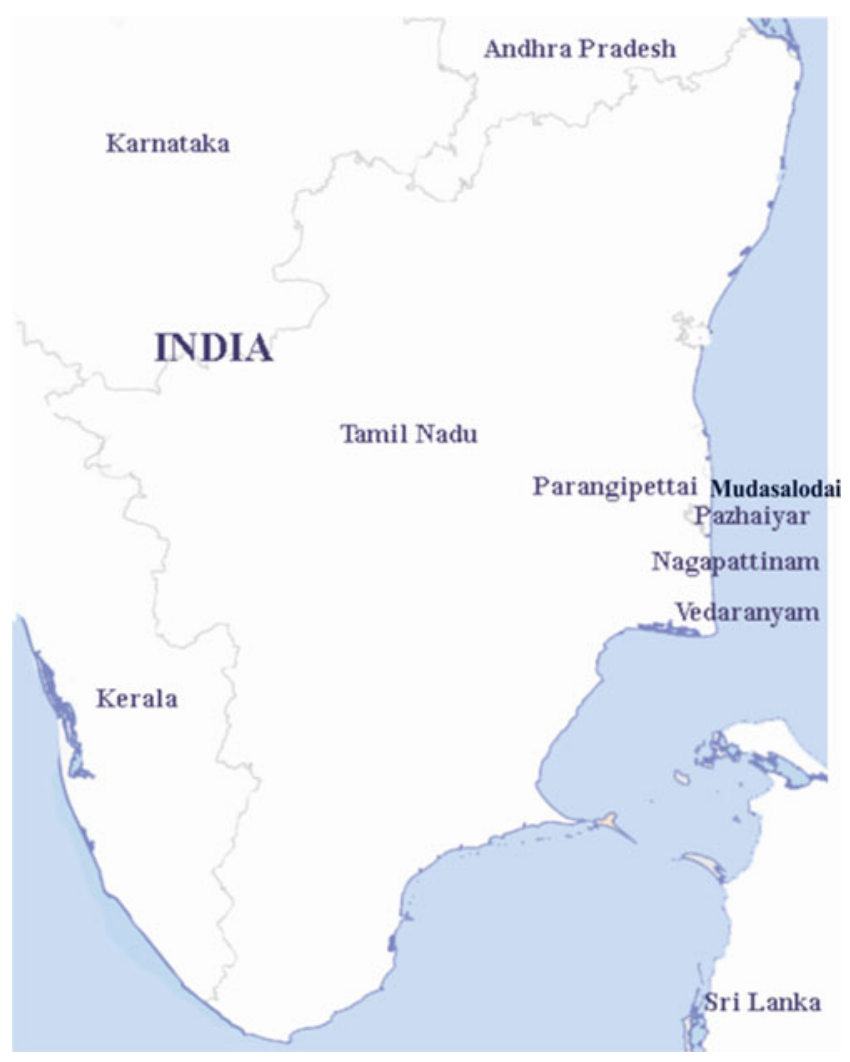

Fig. 1 Map showing the sampling area
Abbreviations used: AUCR - Annamalai University, collection Ravichandran, MNHN-Museum National d' Histoire Naturelle, Paris.

\section{Results}

Taxonomic remarks

Eleven Nerocila species were reported in this study. Most of them, Nerocila depressa Milne Edwards 1840, Nerocila longispina Miers 1880, Nerocila loveni Bovallius 1887, N. phaiopleura Bleeker 1857, Nerocila poruvae Rameshkumar et al. 2011, Nerocila serra Schioedte and Meinert 1881, N. sundaica Bleeker 1857, and Nerocila trichiura (Miers 1877), are now well identified. Accurate descriptions with figures of these species have been given by Bowman (1978; Bowman and Tareen (1983), Bruce (1987a), Bruce and HarrissonNelson (1988), and Rameshkumar et al. (2011). Thus, the necessity of redescribing these species does not arise here. Therefore, we are presenting only additional photos of these parasites to contribute to their identification by future workers.

However, the validity of $N$. arres, $N$. exocoeti, and $N$. sigani, was still to be verified.

Nerocila arres Bowman and Tareen 1983

Synonymy: Nerocila arres Bowman and Tareen 1983: 12-17, figs 10-12.-Trilles 1994: 82.- Rameshkumar et al. 2012b: not paginated. Nerocila sigani Bowman and Tareen 1983. Bruce and Harrison-Nelson 1988: 597-598 (part).

Material examined: 17 Nerocila arres, female (14 ovigerous, size from 20 to $28 \mathrm{~mm}$, No. MNHN-IU-2009-1934 and AUCR 473 to $484 ; 3$ nonovigerous, size from 17 to $19 \mathrm{~mm}$, No. AUCR 485 to 487), Nagappatinam, Southeastern coast of India, on Nemipterus japonicus, 08 January 2011 and 01 April 2011 (Fig. 2a).

Description of the ovigerous female (Figs. $3 \mathrm{a}-\mathrm{c}, 4 \mathrm{a}-\mathrm{q}$, and 6a-e): Body about 2.0 times as long as wide, widest between pereonites $6-7$. Cephalon 0.75 as long as wide, rounded anteriorly. Eyes with facets almost indistinct. Antennulae not widely separated at base. Pereonites 6-7 longest and subequal, 1 and 5 subequal in length, shorter than 6-7, 2-4 shortest and subequal. Posterolateral angles of all pereonites produced into points increasing in length from 1 to 7 ; pereonites 5-7 with broad posteroventral corners. Coxae 2-7 visible in dorsal view, produced into pointed and narrow (2-5) or pointed and broad (6-7) processes; $2-5$ not extending beyond posterior of pereonites, 6-7 slightly longer than their respective segment or subequal. All pleonites visible, one longer than $2-5$ subequal in length, ventrolateral margins of pleonites 1-2 slightly enlarged, posteriorly directed, extending distinctly beyond pleonite 5 , pleonite $3-5$ not produced. Pleotelson nearly as wide as long or $1 / 3$ wider than long, lateral margins curving to medial point. 


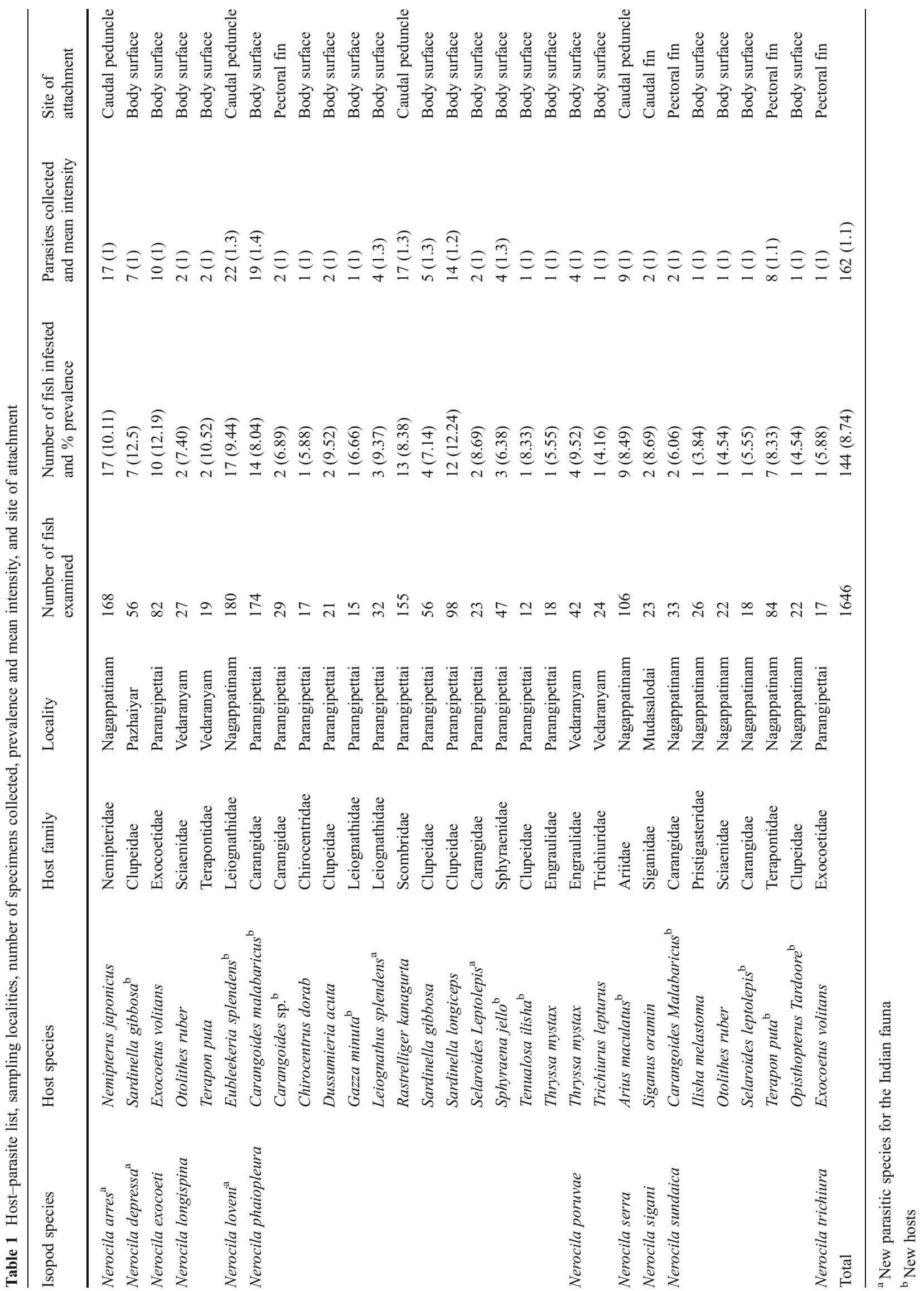


Fig. 2 a-k All the Nerocila species (dorsal view) collected from India in this study: Fig. 2a, $N$. arres; Fig. 2b, $N$. depressa; Fig. 2c, N. exocoeti; Fig. 2d, $N$. longispina; Fig. 2e, N. loveni; Fig. 2f, N. phaiopleura; Fig. 2g, $N$. poruvae; Fig. 2h, N. serra; Fig. 2i, N. sigani; Fig. 2j, $N$. sundaica; Fig. 2k, N. trichiura
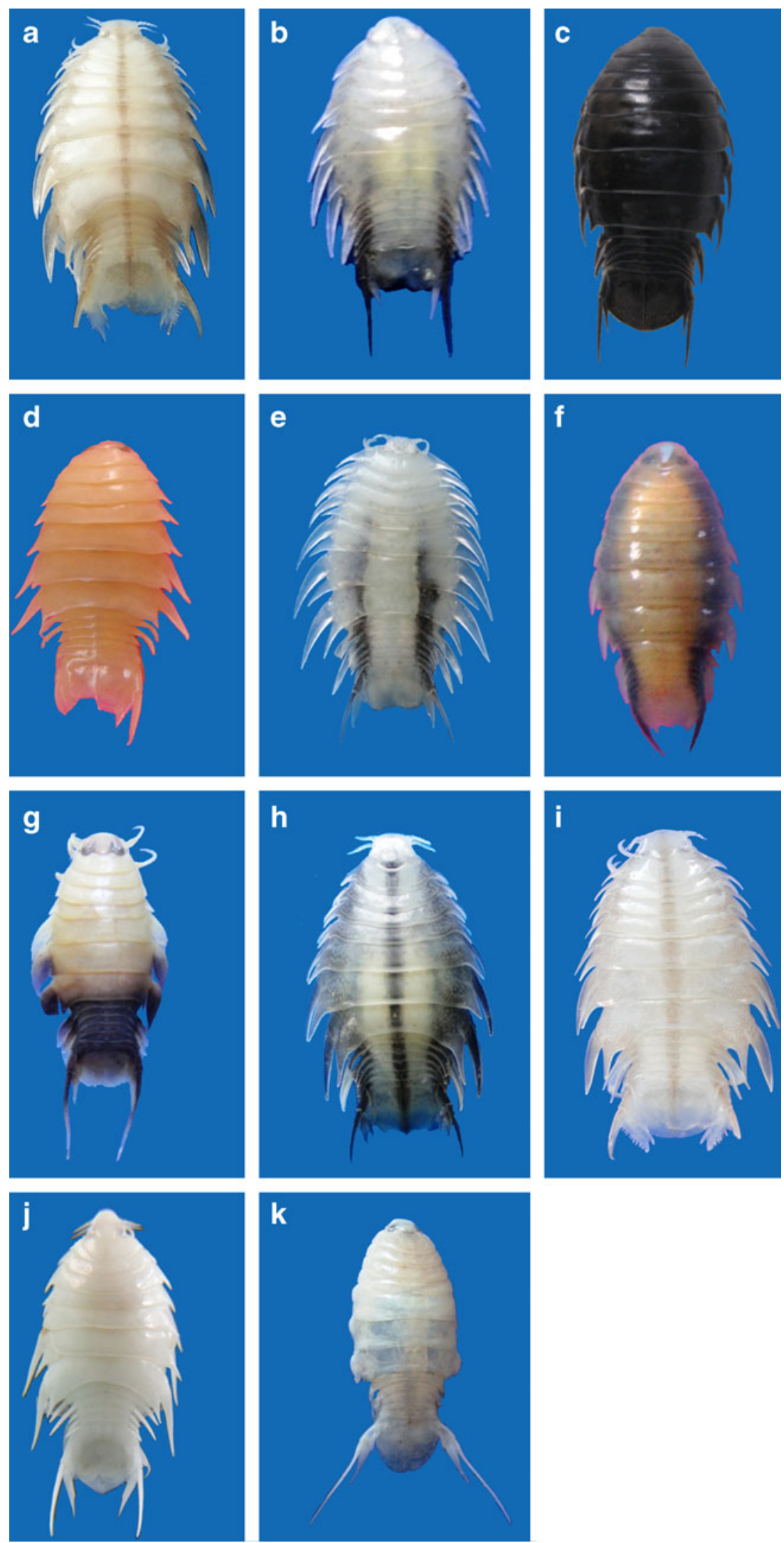

Antennula 8 articled, 1-2 larger than 3-8; article 4-7 with esthetes, article 8 with esthetes and spiny setae.
Antenna with nine articles, 1-2 larger than 3-9, article 4 with two plumose setae, $8-9$ with four spiny setae. 
Fig. 3 a-h $N$. arres Bowman and Tareen 1983, ovigerous female (MNHN-IU-20091934): a dorsal view; b lateral view; c frons; $\mathbf{d}$ uropods. $N$. sigani Bowman and Tareen 1983, ovigerous female (MNHN-IU-2009-1935): e dorsal view; f lateral view; $\mathbf{g}$ frons; $\mathbf{h}$ uropods. Scale lines represent $0.5 \mathrm{~mm}$
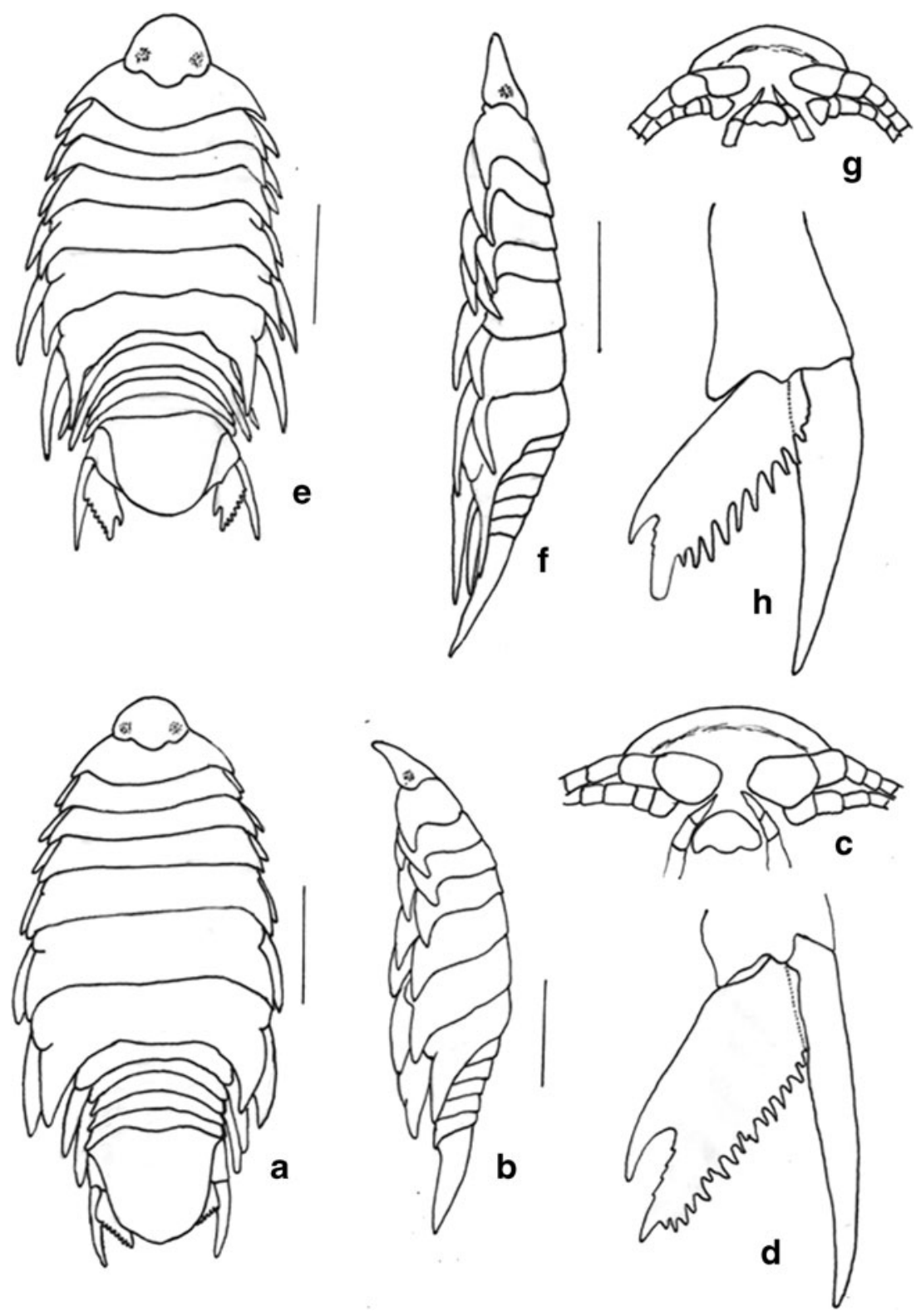

Mandibular palp article 1 largest, with seven irregular smoothly rounded setae at apex of third article. Maxillula with three terminal spines. Maxilla with two spines on medial lobe and one spine on lateral lobe. Maxilliped with oostegial lobe, distal palp segment with five spines. Pereopods 1-5 without marginal hooked spines, pereopod 6 with one spine on merus, four spines on carpus, and five spines on propodus, pereopod 7 with two rows of three and 5 spines respectively on merus, two rows of three and four spines on carpus and a row of seven spines on propodus. Dactyls of pereopods 1, 2, 4, and 5 with distinct swellings. Pleopods 1-2 with five coupling hooks on protopod medial margin; pleopod 2 with appendix masculina about 0.5 length of endopod; endopod 1-5 with proximomedial lobe well developed, 1-2 not folded, 3-5 folded; endopod 3-4 with few folds, pleopod 5 endopod with several large folds. Exopod of uropod longer than endopod; endopod not extending, or slightly, beyond posterior margin of pleotelson, with very deep notch on medial margin and serrate lateral margin with a row of 15-16 dissimilar teeth.

Nerocila sigani Bowman and Tareen 1983

Synonymy: Nerocila sigani Bowman and Tareen 1983: 12, Fig. 9.-Bruce 1987: 406-Bruce and Harrison-Nelson 1988: 597-598 (part).—Trilles 1994: 100 (part).—Kensley 2001: 234. - Rameshkumar et al. 2012b: not paginated.

Material examined: two $N$. sigani, female (ovigerous, size 25 mm, No. MNHN-IU-2009-1935 and AUCR 655), Mudasalodai, Southeastern coast of India, on Siganus oramin, 09 December 2011.

Description of the ovigerous female (Figs. 3e-h, $5 \mathrm{a}-\mathrm{n}$, and $6 \mathrm{f}-\mathrm{j}$ ): body about 2.0 times as long as wide, widest between pereonites 5-6. Cephalon as wide as long, anterior margin rounded. Eyes with facets almost indistinct. Antennulae widely 
Fig. 4 a-q $N$. arres Bowman and Tareen 1983, ovigerous female (MNHN-IU-20091934): a antennule; b antennule, distal articles; c antenna; d antenna, distal articles; e mandible; f mandible palp, apex; g maxillule; h maxilla; I, maxilliped; j-p, pereopods $1-7$; q pereopod 7 , distal articles

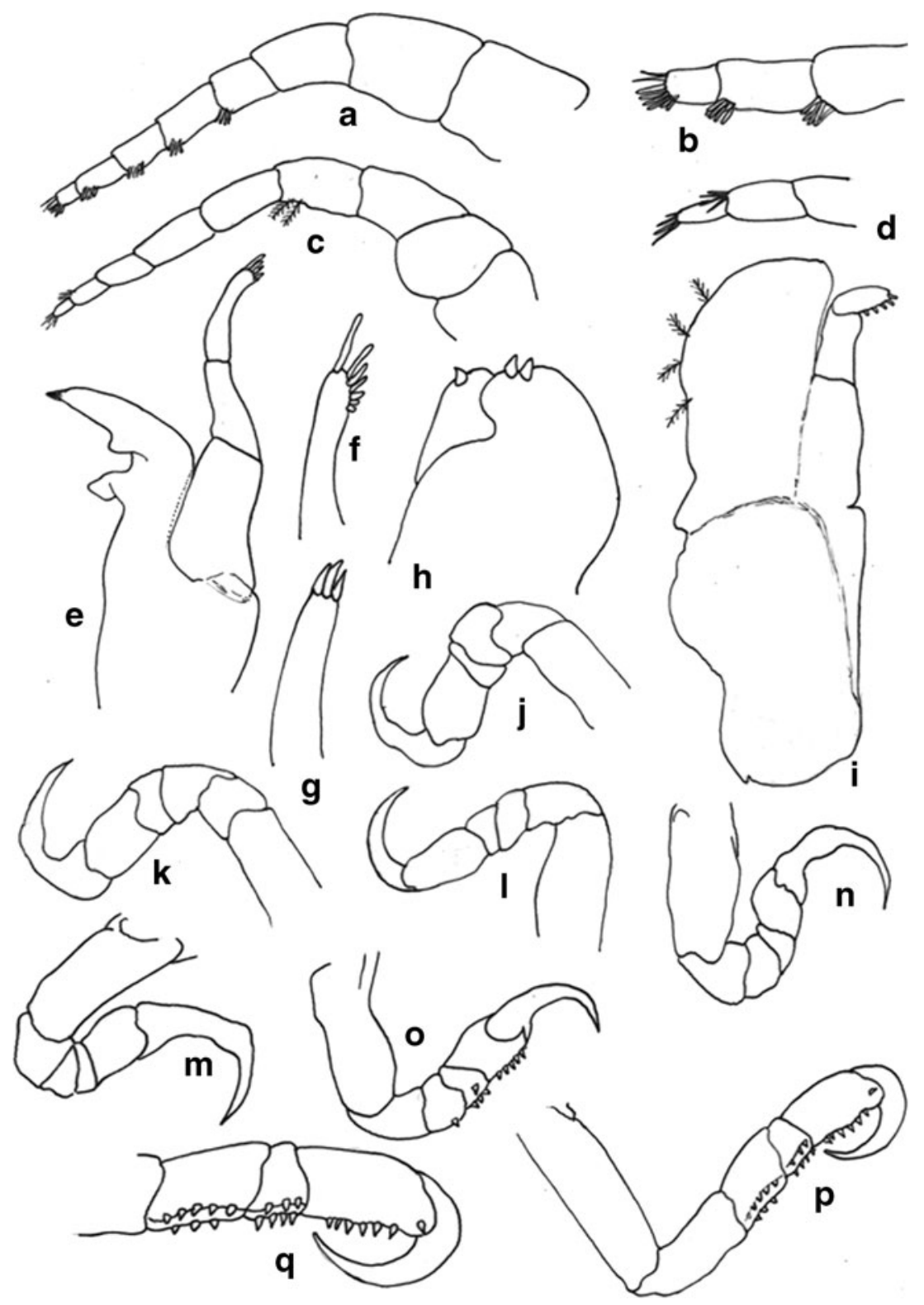

separated at base. Pereonites 1, 5, 6, and 7 subequal in length, longest; 2-4 shortest and subequal. Posterolateral angles of all pereonites produced into points narrow and acute, increasing in length progressively from pereonite 1 to pereonite 7 . Coxae 2-7 visible in dorsal view, produced into pointed and narrow processes; 2-5 not extending beyond posterior of pereonites or shortest; 6-7 distinctly longer than their respective segment and much more longer than the anterior. All pleonites visibles; ventrolateral margins of pleonites 1-2 narrow and acute, posteriorly directed, extending to pleonite 5 or slightly beyond pleonite 5 respectively; pleonites $3-5$ slightly produced. Pleotelson about 1/3 wider than long or as wide as long, smoothly rounded, without caudomedial lobe.

Antennula 8 articled, 1-2 larger than 3-8; articles 4-7 each with dense posterodistal cluster of esthetes. Antenna with 10 articles, 1-2 larger than the others, 5-10 with esthetes or spiny setae. Mandibular palp article 1 largest, article 2 with one spiny seta and three unequal spiny setae at apex of third article. Maxillula with three terminal spines. Maxilla with five spines on medial lobe and one spine on lateral lobe. Maxilliped with oostegial lobe, distal palp segment with one medial and five terminal spines. Pereopods 1 , 2, 4, and 5 without marginal hooked spines, pereopod 3 with two spines on propodus, pereopod 6 with two spines on merus, three on carpus, and five on propodus, pereopod 7 with one spine on ischium, merus with two rows of five spines, carpus with two rows of three and five spines respectively, propodus with a row of 7 spines. Dactylus of pereopods without distinct swellings or only very weak swellings on dactyls 4 5. Pleopods 1-2 with five coupling hooks on protopod medial margin; pleopod 2 with appendix masculina about $0.6 / 0.7$ length of endopod and proximomedial lobe not folded; 
Fig. 5 a-n N. sigani Bowman and Tareen (1983), ovigerous female (MNHN-IU-20091935): a antennule; b antenna; c mandible; $\mathbf{d}$ mandible palp; e maxillule; $\mathbf{f}$ maxilla; $\mathbf{g}$ maxilliped; $\mathbf{h}$ maxilliped article $3 ; \mathbf{i}-\mathbf{m}$ pereopods $3-7 ; \mathbf{n}$ pereopod 7, distal articles

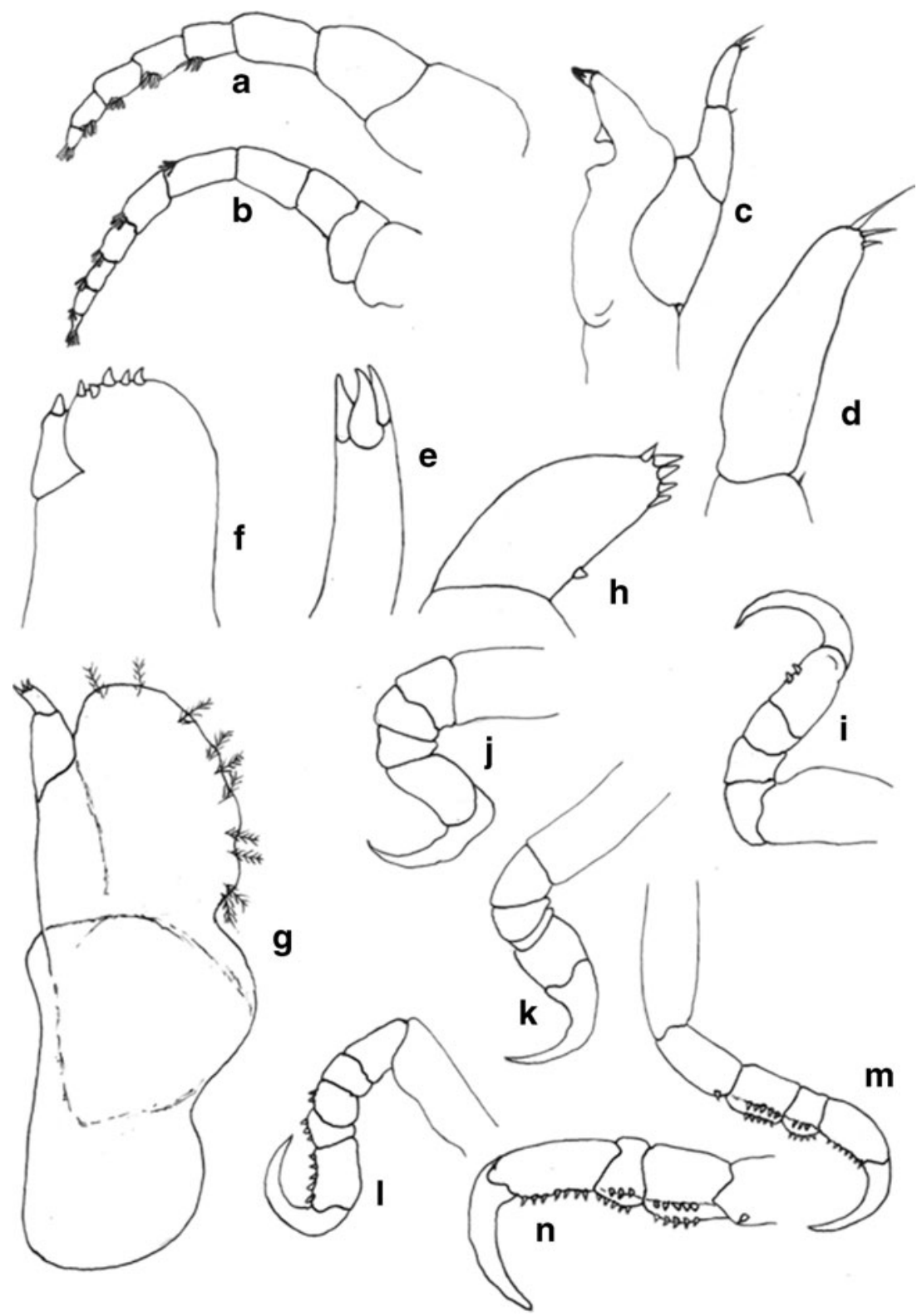

endopod 3-5 with proximomedial lobe well developed, folded; pleopod 3-4 endopod with a single fold or twofold, pleopod 5 endopod with several large folds. Uropod rami extending beyond posterior margin of pleotelson; exopod slightly longer than endopod; endopod with deep notch on medial margin and serrate lateral margin with a row of 10 regular teeth.

Nerocila exocoeti Pillai 1954.

Synonymy: Nerocila exocoeti Pillai 1954: 12-13.Kurochkin 1980: 289.-Bruce, 1987: 404.-Bruce and Harrison-Nelson 1988: 592-593.-Bruce and Bowman 1989: 1.—Trilles 1994: 89.-Kensley 2001: 233.Sivasubramanian et al. 2011: 99-101.

Material examined: 10 female specimens [eight ovigerous , size from 25 to $28 \mathrm{~mm}$, No. MNHN-IU-2009-1936, MNHN-IU-2009-1937 (Neotype) and AUCR 500 to 505; two non-ovigerous, size from 22 to $23 \mathrm{~mm}$, No. AUCR 506 and 507], Parangipettai, Southeastern coast of India, on Exocoetus volitans, 12 April 2011.

Description of the ovigerous female (Figs. 7a-i, 8a-m, and $9 \mathrm{a}-\mathrm{e})$ : Body about $2.5-2.8$ as long as wide, widest between pereonite 5-6; cephalon anterior margin rounded; eyes with facets almost indistinct; Pereonites 1 and 5-7 longest, 2-4 subequal; pereonite 7 sometimes slightly shortest; posterior angles of pereonites 1-6 not produced; posterolateral angles of pereonite 7 produced backward into a pointed process; Coxae 2-4, often visible in dorsal view, produced into rounded processes, not exceeding beyond posterior of pereonites; Coxae 5-7, much more long than the anterior, posterior margin acute, reaching or extending slightly or distinctly beyond posterior of pereonites; All pleonites visibles, pleonite 1 shortest, pleonite 5 longest and widest, pleonies 2-4 subequal; Ventrolateral margins of pleonites 1-2 
Fig. 6 a-j $N$. arres Bowman and Tareen 1983, ovigerous female (MNHN-IU-20091934): a-e, pleopods $1-5$. N. sigani Bowman and Tareen 1983, ovigerous female (MNHN-IU-2009-1935): $\mathbf{f}-\mathbf{j}$ pleopods $1-5$
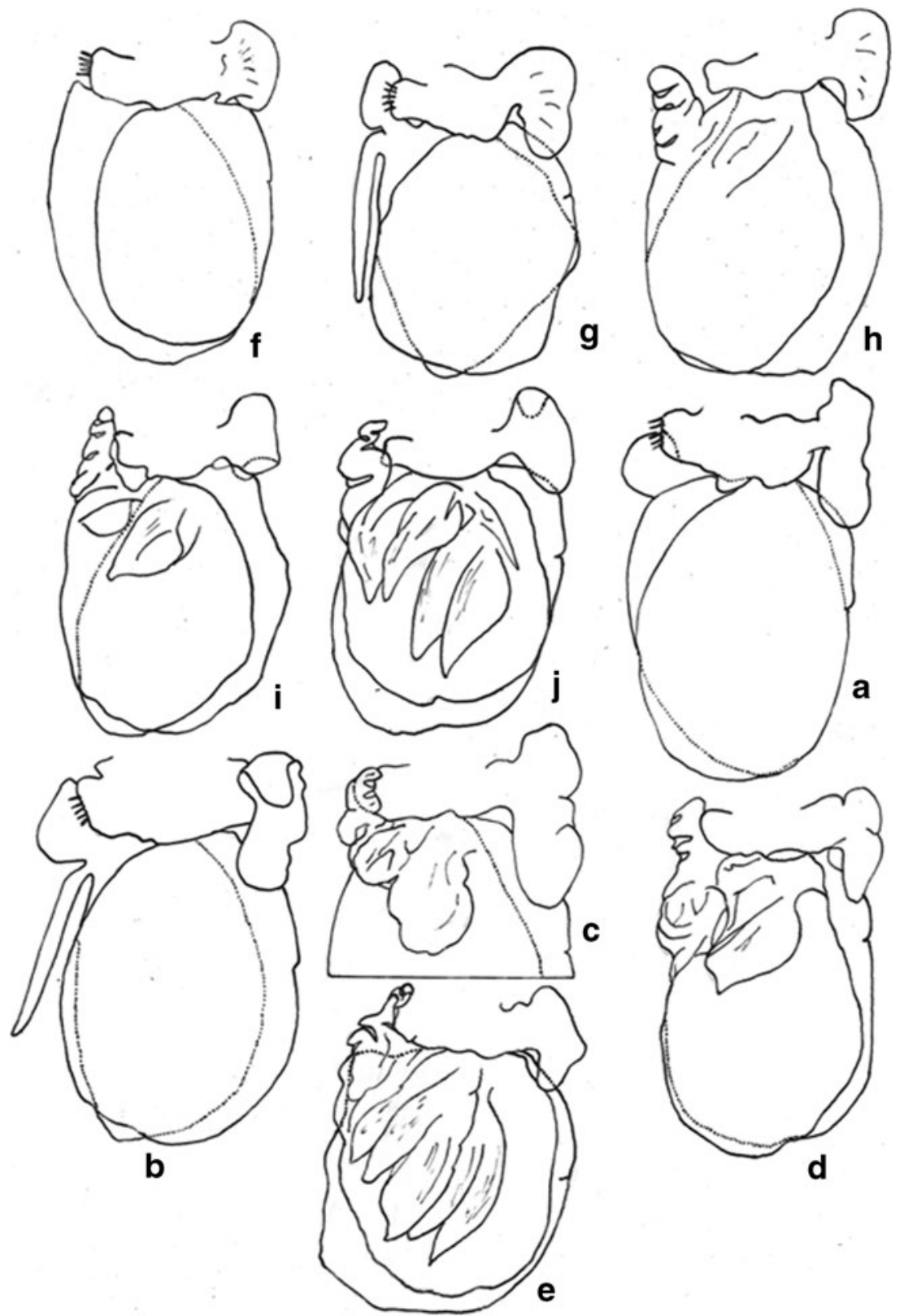

posteriorly directed and acute, extending to pleonites 3-4 or beyond pleonite 5, respectively; pleonites 3-5 lateral margins weakly acute; pleotelson $0.75-0.9$ as long as wide, lateral margins convex, converging to indistinct apical point.

Antennula distinctly thicker than antenna, 8 articled, articles 5-8 each with posterodistal cluster of esthetes; antenna, 10 articled, 7-10 with setae. Mandible palp article 1 largest and article 3 without setae on distolateral margin; maxillula with three terminal spines; maxilla with two spines on medial lobe and one spine on lateral lobe; maxilliped with oostegial lobe, distal palp segment with three terminal spines. All pereopods without marginal spines, dactylus longer than propodus; pleopods 1-2 with all rami lamellar, three or four couplings hooks on protopod medial margin of pleopod 1 only, endopod proximomedial lobe well-developed but not folded; pleopod 2 with appendix masculina about 0.5 length of endopod; pleopods 3-4 endopod with a single or double lobe, proximomedial lobe well-developed and folded; pleopod 5 endopod with several large folds and proximomedial lobe well-developed and folded. Uropod slender, tapering and sublinear exopod and endopod, exopod about two times longer than endopod; endopod reaching or extending scarcely beyond the posterior margin of pleotelson; exopod extending by far beyond it.

As already reported by Pillai (1954), the entire body of the specimens was steel blue in color, with many chromatophores.

Host-parasite relationships

One hundred and sixty-four parasitic isopods belonging to 11 cymothoid species (Table 1, Figs. 2a-k) were collected. 
Fig. 7 a-j N. exocoeti Pillai 1954, ovigerous female: MNHN-IU-2009-1936. a dorsal view; c lateral view; d frons; e uropods; $\mathbf{f}$ antennule; $\mathbf{g}$ antennule, distal articles; $\mathbf{h}$ antenna; $\mathbf{i}$ antenna, distal articles. MNHNIU-2009-1937. b, dorsal view; c, lateral view. N. trichiura (Miers 1877), ovigerous female (AUCR 497): $\mathbf{j}$ dorsal view. Scale lines represent $5.0 \mathrm{~mm}(\mathbf{a}$, j)) and $5.5 \mathrm{~mm}(\mathbf{b}, \mathbf{c})$
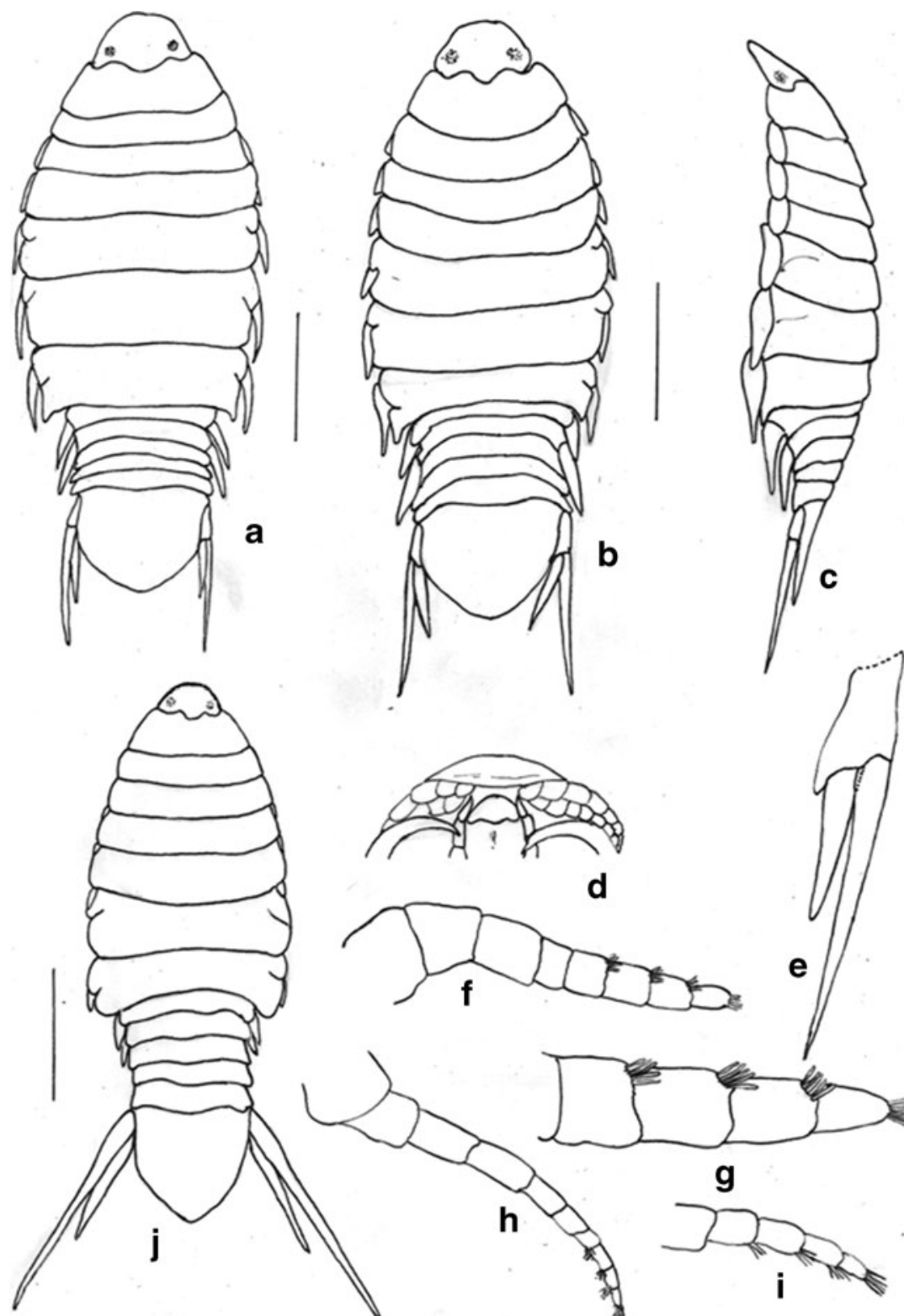
$\sqrt{ }$
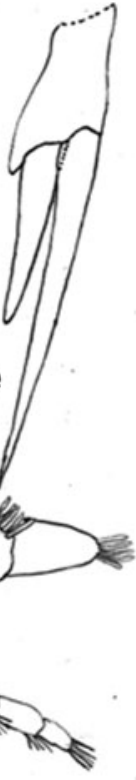

Among them, $N$. arres, $N$. depressa, and $N$. loveni are recorded for the first time from India. These 11 species were collected from 144 fish hosts belonging to 22 species and 15 families: Carangidae, Leiognathidae, Nemipteridae, Sciaenidae, Scombridae, Siganidae, Sphyraenidae, Terapontidae and Trichiuridae (Perciformes), Chirocentridae, Engraulidae, Pristigasteridae and Clupeidae (Clupeiformes), Ariidae (Siluriformes), and Exocoetidae (Beloniformes) (Table 1). Carangidae and Clupeidae are the most parasitized with three and five species, respectively.

$N$. arres, $N$. loveni, $N$. serra, and $N$. sundaica were widely distributed in the Nagappattinam. $N$. poruvae and $N$. longispina showed an extensive Vedaranyam distribution. $N$. loveni and $N$. depressa occurred only in Pazhaiyar region and $N$. sigani along the Mudasalodai coast. $N$. exocoeti, $N$. phaiopleura, and $N$. trichiura, appeared to be limited to the Parangipettai coast (Table 1).

From April 2009 to December 2011, the overall prevalence reached $8.74 \%$. A maximum prevalence was observed in $N$. depressa parasitizing Sardinella gibbosa $(P=$ $12.5 \%$ ) and a minimum prevalence in $N$. sundaica parasitizing Ilisha melastoma $(P=3.84) \%$. The mean intensity ranged from 1 to 1.4 (Table 1).

For some species, the host-isopod association was not very specific. $N$. phaiopleura was collected from 13 host species belonging to seven families and 11 genera.and $N$. sundaica from six host species belonging to five families and six genera. These two species show a euryxenic parasitic specificity. While $N$. exocoeti and $N$. trichiura, only collected from the flying fish $E$. volitans, and $N$. sigani, only 
Fig. 8 a-m $N$. exocoeti Pillai 1954, ovigerous female (MNHN-IU-2009-1936): a mandible; $\mathbf{b}$ maxillule; $\mathbf{c}$ maxilla; $\mathbf{d}$ maxilla, apex; e maxilliped; f maxilliped article 3 ; $\mathbf{g}-\mathbf{m}$, pereopods $1-7$

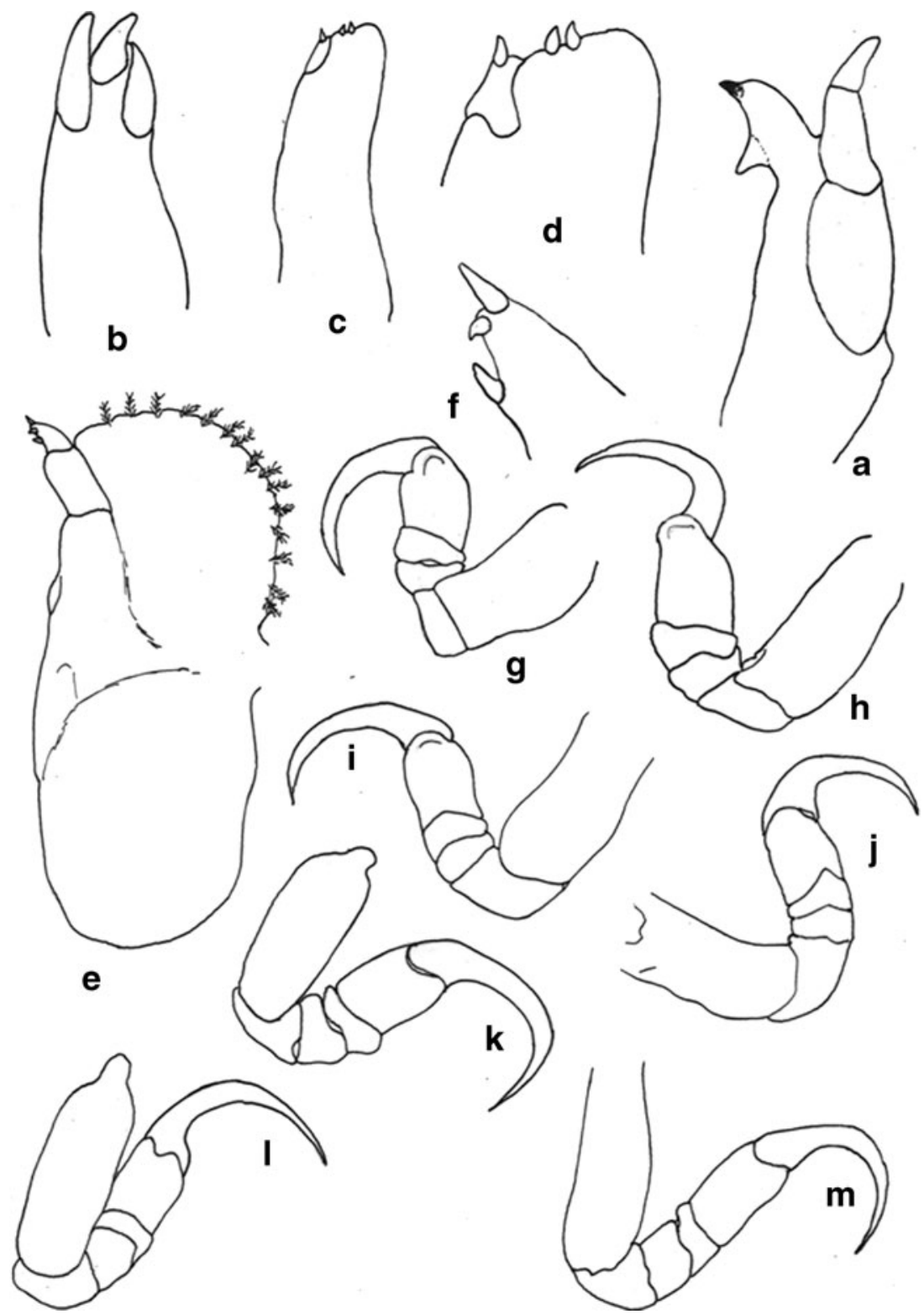

collected on the rabbit fish Siganus oramin, show an oïoxenic parasitic specificity. Carangoides malabaricus, E. volitans, Leiognathus splendens, Otolithes ruber, Sardinella gibbosa, Selaroides leptolepis, Terapon puta, and Thryssa mystax were parasitized by at least two species of Nerocila. Fifteen new hosts were identified, seven for $N$. phaiopleura, four for $N$. sundaica, and one for $N$. depressa, $N$. exocoeti, $N$. loveni, and N. serra (Table 1).

Four species, $N$. arres, $N$. loveni, $N$. serra, and $N$. sigani, were attached on the caudal peduncle or on the caudal fin of the fishes. $N$. depressa, $N$. exocoeti, $N$. longispina, N. phaeopleura, N. poruvae, N. sundaica, and $N$. trichiura, were collected from the body surface, on the head, on the pectoral fin or from the caudal peduncle of hosts.

\section{Discussion}

In the present study, 11 Nerocila species were collected and $N$. arres, $N$. exocoeti, and $N$. sigani were redescribed.

$N$. arres and $N$. sigani were described by Bowman and Tareen (1983). They were collected on Nemipterus japonicus, Nemipterus tolu, Epinephelus tauvina, Acanthopagrus latus (N. arres; Holotype from N. japonicus), and Siganus oramin (N. sigani; Holotype from S. oramin) from Kuwait (Arabian Gulf). These two species were accepted as valid by Bruce (1987a) and Trilles (1994). However, they were synonymized by Bruce and Harrisson-Nelson (1988). These authors stated that $N$. sigani is the senior synonym to $N$. arres, but without an examination of specimens from the host fishes recorded by Bowman and Tareen (1983). Indeed, the material examined 
Fig. 9 a-e $N$. exocoeti Pillai 1954, ovigerous female (MNHN-IU-2009-1936): a-e, pleopods $1-5$
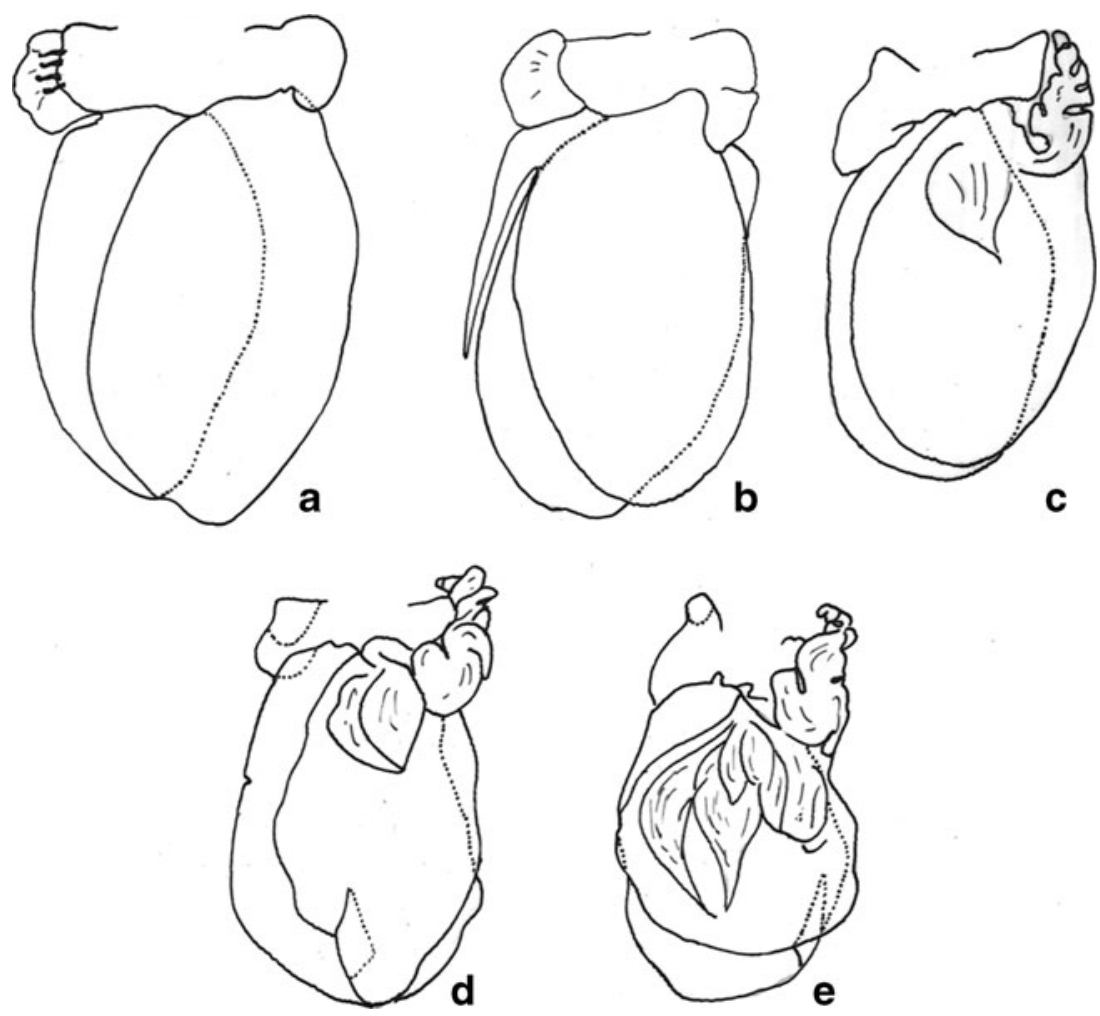

C by Bruce and Harrisson-Nelson was collected on Sciaenia dussumieri, Argyrosoma hololepidotus, Argyrosoma macrocephalus, Argyrosoma nibe, Parastromateus niger, and Pomadasys sp. Thus, it was interesting to benefit from our material to verify the validity of the species $N$. arres and $N$. sigani. We redescribed here in detail the specimens that we collected respectively from the type hosts $N$. japonicus and $S$. oramin, including the mouthparts not examined by Bowman and Tareen (1983) and Bruce and Harrisson-Nelson (1988). Our results reveal that the synonymy of these two species cannot be maintained. Indeed, $N$. sigani and $N$. arres can be distinguished mainly by: cephalon as wide as long (N. sigani) or 0.75 as long as wide ( $N$. arres); antennulae more separated at base in $N$. sigani; posteroventral corners of all pereonites shaped into points and coxae with pointed processes longer, narrower, and more acute in $N$. sigani than in $N$. arres; pleotelson smoothly rounded ( $N$. sigani) or with lateral margins curving to medial point ( $N$. arres); pereopods without distinct swellings in dactyls (N. sigani) or with distinct dactylus nodules in $\mathrm{P} 1, \mathrm{P} 2, \mathrm{P} 4$, and $\mathrm{P} 5$ ( $N$. arres); posterior margin of pleonites 1 and 2 longer, narrower, and more acute in $N$. sigani than in $N$. arres; uropod serrations on the lateral margin of endopod distinct, with 10 regular teeth in $N$. sigani and 1516 dissimilar teeth in $N$. arres; maxilla with five spines on medial lobe and one spine on lateral lobe ( $N$. sigani) or two spines on median lobe and one spine on lateral lobe ( $N$. arres); mandible palp article 3 with three setae on the distolateral margin (N. sigani) or seven setae (N. arres). Our drawings does not match the illustrations produced by Bruce and Harrisson-Nelson (1988) for two specimens, one collected from an unknown Malaysian host (USNM 232015) and another found on Argyrosoma nibe from Taiwan (USNM 232017), certainly not belonging to $N$. arres and $N$. sigani. Some drawings from Bowman and Tareen (1983) for two specimens collected respectively from $A$. latus and E. tauvina does not correspond to $N$. arres.

N. exocoeti was identified by Pillai (1954) from a large number of specimens in all stages of development collected on Parexocoetus brachypterus from Travancore, India. However, no figures have been published. The author specified only that the main distinguishing character of this species is the comparative size of the coxal plates, the second being small, not extending beyond the posterior border of the segment and the seventh reaching the tip of the first pleon segment, and that the entire body is steel blue in color. Males were collected but not described by Pillai (1954). N. exocoeti was later collected on $P$. brachypterus and Scomberomorus multiradiatus (gut contents?) from Papua New Guinea, Indonesia, and Taiwan by Bruce and Harrisson-Nelson 1988). Figures of one specimen (photos of the dorsal and ventral view) collected on the flying fish E. volitans from the Parangipettai Coast, South-East coast of India, were recently published (Sivasubramanian et al. 2011). N. exocoeti remained a poorly known species. A detailed redescription of this species was necessary.

Until now, two Nerocila species, N. exocoeti and N. trichiura (Miers 1877) were collected from fishes belonging to 
the family Exocoetidae. Due to some marked differences, these two species are readily distinguishable. Indeed, in N. trichiura (Fig. 7j), the anterior margin of the cephalon is subtruncate, the posterior angle of pereonite 7 does not extend posteriorly in an acute process, the coxae $2-7$ are produced into a rounded process, the ventrolateral margins of pleonites $1-2$ are distinctly shorter than in $N$. exocoeti; the uropods are much longer, exopod and endopod extending far beyond the distal margin of pleotelson; the live specimens are whitish (Fig. 2k).

While the holotype of $N$. trichiura is held at the British Museum (Natural History) (Holotype: 1846: 104. Mauritius. Presented by Robert Templeton), the Pillai's Indian specimens of $N$. exocoeti are not extant. Thus, the specimen MNHN-IU2009-1937 is designate here as neotype of $N$. exocoeti.

Until now, 17 Nerocila nominal species and four parasites not yet identified to the species level were recorded from India (Electronic supplementary material). The validity of several of them is still to be verified. Nerocila madrasensis was poorly described by Ramakrishna and Venkata Ramaniah (1978) who suggested that this species resembles to $N$. serra and $N$. trichiura. Possibly related to $N$. trichiura according to Bruce (1987a), N. madrasensis and N. trichiura were provisionally synonymized by Trilles (1994) and Trilles et al. (2011). Nerocila pigmentata was synonymized with $N$. depressa by Trilles (1975), 1994), Bruce and Harrison-Nelson (1988) and Trilles et al. (2011) but it will be useful to verify once more this synonymy. Besides that, the species identified by Parimala (1984) as $N$. pigmentata is of uncertain identity and clearly not $N$. depressa (Bruce and Harrisson-Nelson 1988). Nerocila priacanthusi, resembles to $N$. serra according to Kumari et al. (1987). However, since the endopod of uropod of this species is with deep notchs on lateral margin as figured by the authors, this species is really similar to $N$. arres. This species is maybe a junior synonym of $N$. arres (Trilles et al. 2011). Nerocila pulicatensis was not reported since its original description by Jayadev Babu and Sanjeeva Raj (1984). Possibly related to Nerocila latiuscula, the description provided by the authors precludes for the moment assessment of the status of this species. Nerocila recurvispina was also not reported since its original description by Schioedte and Meinert (1881) from a single specimen collected at Calcutta on an unknown fish host. Additional specimens are required to describe this species according to modern standards or to verify if it remains a valid species. Nerocila trivittata is maybe the senior synonym of $N$. serra (Trilles 1979). However, Bowman and Tareen (1983) suggested that the question of the identity of $N$. trivittata and $N$. serra cannot be resolved now because the type of $N$. trivittata is not extant.

\footnotetext{
Acknowledgments Authors are thankful to the Department of Science and Technology and to the Ministry of environment and Forest, Government of India for providing financial support and to the Dean, Faculty of Marine Sciences, Annamalai University, Parangipettai for providing facilities and encouragement.
}

Open Access This article is distributed under the terms of the Creative Commons Attribution License which permits any use, distribution, and reproduction in any medium, provided the original author(s) and the source are credited.

\section{Appendix}

Material deposited

Nerocila arres Bowman and Tareen 1983. Seventeen female specimens (14 ovigerous, size from 20 to $24 \mathrm{~mm}$, No. AUCR 473 to AUCR 484 and MNHN-IU-2009-1934; three nonovigerous, size 17,18 , and $19 \mathrm{~mm}$, No. AUCR 485 to AUCR 487), Nagapattinam, 08 January 2011 and 01 April 2011.

Nerocila depressa Milne Edwards 1840. Seven female specimens (ovigerous, size from 21 to $26 \mathrm{~mm}, \mathrm{~N}^{\circ}$ AUCR 460 to 466), Pazhaiyar, 25 January 2011

Nerocila exocoeti Pillai 1954. Ten female specimens [eight ovigerous, size from 25 to $28 \mathrm{~mm}$, No. AUCR 500 to 505 and MNHN-IU-2009-1936, MNHN-IU-2009-1937 (Neotype); two nonovigerous, size 22 and $23 \mathrm{~mm}$, No. AUCR 506 and 507], Parangipettai, 12 April 2011

Nerocila longispina Miers 1880. Two female specimens (ovigerous, size 20 and $24 \mathrm{~mm}$, No. AUCR 21 and AUCR 22), Vedaranyam, 8 September 2009

Nerocila loveni Bovallius 1887. Twenty-two female specimens (14 ovigerous, size from 20 to $25 \mathrm{~mm}$, No. AUCR 614 to AUCR 627; eight nonovigerous, size from 15 to $18 \mathrm{~mm}$, No. AUCR 628 to AUCR 635), Nagapattinam, 8 January 2011 and 1 April 2011.

Nerocila phaiopleura Bleeker 1857. Seventy-three female specimens (61 ovigerous, size from 18 to $27 \mathrm{~mm}$, No. AUCR 242 to AUCR 302; 12 nonovigerous, size from 14 to $17 \mathrm{~mm}$, No. AUCR 303 to 314), Parangipettai, 3 April 2009, 1 June 2009, 2 January 2010, 3 June 2010, and 5 June 2010.

Nerocila poruvae Rameshkumar, Ravichandran \& Trilles, 2011. Five female specimens (ovigerous, size from 26 to 32 mm, No. AUCR 656 to 660), Vedaranyam, 7 January 2011.

Specimens already deposited: Holotype female (ovigerous, $26 \mathrm{~mm}$, No. MNHN 6288) and three paratypes (ovigerous, 20, 23, and $27 \mathrm{~mm}$ No. AUCR 17 and AUCR 18).

Nerocila serra Schioedte and Meinert 1881. Nine female specimens (ovigerous, size from 21 to $27 \mathrm{~mm}$, No. AUCR 661 to AUCR 669), Nagappatinam, 8 January 2011 and 1 April 2011.

Nerocila sigani Bowman and Tareen 1983. Two female specimens (ovigerous, size $25 \mathrm{~mm}$, No. MNHN-IU2009-1935 and AUCR 655), Mudasalodai, 9 December 2011

Nerocila sundaica Bleeker 1857. Fifteen female specimens (ovigerous, size from 24 to $32 \mathrm{~mm}$, No. AUCR 670 to AUCR 683), Nagappatinam, 8 January 2011 and 1 April 2011 
Nerocila trichiura (Miers 1877). One female specimen (ovigerous, size $38 \mathrm{~mm}$, No. AUCR 497), Parangipettai, 18 June 2011

\section{References}

Bal DV, Joshi UN (1959) Some new isopod parasites on fishes. J Bombay Nat Hist Soc 56:563-569

Barnard KH (1936) Isopods collected by the R.I.M.S. "Investigator". Rec Indian Mus Calcutta 38:147-191

Bleeker P (1857) Recherches sur les Crustacés de l'Inde Archipélagique. II. Sur les Isopodes Cymothoadiens de 1' Archipel Indien. Acta Soc Sci Indo-Neerlandicae 2:20-40

Bovallius C (1887) New or imperfectly known Isopoda. Part III. Bih K Svenska Vetenska-Akad Handl 12:1-23

Bowman TE (1978) Restoration of the subgenus Emphylia Koelbel for the parasitic isopod Nerocila sundaica Bleeker (Flabellifera, Cymothoidae). Crustaceana 34:33-44

Bowman TE, Tareen IU (1983) Cymothoidae from fishes of Kuwait (Arabian Gulf) (Crustacea: Isopoda). Smith Contrib Zool 382:1-30

Bruce NL (1987a) Australian species of Nerocila Leach, 1818, and Creniola n. gen. (Isopoda: Cymothoidae), crustacean parasites of marine Fishes. Rec Aus Mus 39:355-412

Bruce NL (1987b) Australian Pleopodias Richardson, 1910 and Anilocra Leach, 1818 (Isopoda: Cymothoidae), crustacean parasites of marine fishes. Rec Aus Mus 39:85-130

Bruce NL, Bowman TE (1989) Species of the parasitic isopod genera Ceratothoa and Glossobius (Crustacea, Cymothoidae) from the mouths of flying fishes and halfbeaks (Beloniformes). Smith Contrib Zool 489:1-37

Bruce NL, Harrison-Nelson EB (1988) New records of fish parasitic marine Isopod Crustaceans (Cymothoidae, subfamily Anilocrinae) from the Indo-West Pacific. Proc Biol Soc Wash 101:585-602

Brusca RC (1981) A monograph on the Isopoda Cymothoidae (Crustacea) of the eastern Pacific. Zool J Linn Soc 73:117-199

Bush AO, Lafferty KD, Lotz JM, Shostak AW (1997) Parasitology meets ecology on its own terms: Margolis et al. revisited. J Parasitol 83:575-583

Chidambaram K, Devidas Menon M (1945) The isopod parasite Nerocila sundaica, on West Coast food fishes. Curr Sci 14:308

Daniel A, Rama Rao KV (1967) Notes on animal relationships: a flying fish parasitised by an isopod, and a copepod associated with an inquiline cirripede. Curr Sci 36:641

Froese R, Pauly D (2011) FishBase: World Wide Web electronic publication. Available from: http://. Fishbase. Org., version (3/ 2011) (Accessed September 2011

Jayadev Babu S, Sanjeeva Raj PJ (1984) Isopod parasites of fish of Pulicat Lake. Proc Symp Coast Aqua (Fin Fish) 3:818823

Joshi UN, Bal DV (1960) Some New Isopod on Fishes. Proceedings 47th Indian Scientific Congress III, Abstracts, Section VII (Zoology and Entomology) $446 \mathrm{pp}$

Kensley B (2001) Biogeography of the marine Isopoda of the Indian Ocean, with a check-list of species and records. In: Kensley B, Brusca RC (eds) Isopod systematics and evolution. Crustacean Issues 13. A.A. Balkema, Rotterdam/Brookfield, pp 205-264, $357 \mathrm{pp}$

Kumari CJ, Rao KH, Shyamasundari K (1987) A new cymothoid isopod of the genus Nerocila Leach (Crustacea: Isopoda: Flabellifera) parasitic on marine fishes of Waltair coast, India. Revist Ibéri de parasitol 47:413-417
Kurochkin YV (1980) On the parasitic fauna of flying fishes (family Exocoetidae) in the world ocean. Akademii Nauk, Trudy Instituta Okeanografii 97:276-296 (In Russian with English summary)

Margolis L, Esch GW, Holmes JC, Kuris AM, Schad GA (1982) The use of ecological terms in parasitology (report of an ad hoc Commitee of the American Society of Parasitologists). J Parasitol 68:131-133

Meenakshisundaram PT (1965) A note on host specificity of the isopod parasite Nerocila sp. J Mar Biol Ass India 7:202-204

Miers EJ (1877) On a collection of Crustacea, Decapoda, and Isopoda, chiefly from South America, with descriptions of new genera and species. Proc Zool Soc Lond 43:652-679

Miers EJ (1880) On a collection of Crustacea from the Malaysian Region-Part IV. Penaeidea, Stomatopoda, Isopoda, Suctoria and Xiphosura. Ann Mag nat Hist 5, series 5, no. XXX, note XLI: $457-472$

Milne Edwards HM (1840) Histoire Naturelle des Crustacés comprenant l'anatomie, la physiologie et la classification de ces animaux III. Librairie Encyclopédique de Roret, Paris, p 605

Monod T (1931) Sur quelques crustacés aquatiques d'Afrique (Cameroun et Congo). Revue Zool Bot Afr 21:1-36

Parimala S (1984) Nerocila pigmentata Bal \& Joshi (Isopoda: Cymothoidae) parasitic on Nematalosa nasus (Bloch). J Mar Biol Ass India 21(for 1979):180-181

Pillai NK (1954) A preliminary note on the Tanaidacea and Isopoda of Travancore. Bull Cent Res Inst Univ Travancore 3(series C):1-21

Pillai NK (1960) Ectoproctan-Coelenterate association: an example of unpurposeful inquilinism? J Bombay Nat Hist Soc 57:693-694

Pillai NK (1964) Parasitic isopods of the family Cymothoidae from South Indian fishes. Parasitology 54:211-223

Rajkumar M, Perumal P (2004) Effect of Isopod parasite, Nerocila pheaopleura on Stolephorus commersonii fish from Parangipettai coastal waters (South East Coast of India). Appl Fish Aqua IV 2:17-23

Rajkumar M, Thavasi R, Perumal P, Trilles JP (2007) Parasite induced Vibriosis in Stolephorus commersonii. Res J Microbiol 2:972-977

Rajkumar M, Thavasi R, Trilles JP Perumal P (2008) Vibriosis and parasitic isopod infections in the Black Fin Sea Catfish, Arius jella. In: V.B./Sakhare (ed) Advances in Aquatic Ecology. Daya Publishing House, New Delhi-35, pp 102109, 2, Chapter 13

Ramakrishna G, Ramaniah V (1978) A new cymothoid of the genus Nerocila from Madras. Bull Zool Sur Ind 1:177-180

Rameshkumar G, Ravichandran S (2010) New host record, Rastrelliger kanagurta, for Nerocila phaeopleura parasites (Crustacea, Isopoda, Cymothoidae). Mid East J Sci Res 5:54-56

Rameshkumar G, Ravichandran S, Trilles JP (2011) Cymothoidae (Crustacea, Isopoda) from Indian fishes. Acta Parasitol 56:78-91

Rameshkumar G, Ravichandran S, Trilles JP (2012a) Observation on an isopod parasitizing the edible fish Parastromateus niger in the Parangipettai coast of India. J Environ Biol 33:191-193

Rameshkumar G, Ravichandran S, Sivasubramanian K, Trilles JP (2012b) New occurrence of parasitic isopods from Indian fishes. J Parasit Disea (published Online 17 June 2012; doi:10.1007/ s12639-012-0128-x)

Ranjitsingh AJA, Padmalatha C (1997) Parasitic infestation on commercially important sardines. Curr Sci 72:171

Ravichandran S, Ranjith Singh AJA, Veerappan N (2001) Parasite induced vibriosis in Chirocentrus dorab off Parangipettai coastal waters. Curr Sci 80:101-102

Ravichandran S, Ramesh Kumar T (2004) Infestation of isopod parasite Nerocila phaeopleura on Chirocentus dorab. Proceedings National Seminar on Marine Resources. ST. Hindu College, Nagercoil: $45-48$ 
Ravichandran S, Ramehkumar G, Balasubramanian T (2010) Infestation of isopod parasites in commercial marine fishes. J Parasit Dis 34:97-98

Sarusic G (1999) Preliminary report of infestation by isopod Ceratothoa oestroides (Risso, 1826), in marine cultured fish. Bull Eur Ass Fish Pathol 19:110-112

Schioedte JC, Meinert F (1881) Symbolae ad Monographiam Cymothoarum Crustaceorum Isopodum Familiae. II. Anilocridae. Naturhist Tidsskr Ser III 13:1-166

Seshagiri Rao BV (1974) Observation on the host specificity of isopod parasite Nerocila sp. from Andhra coast. Curr Sci 43:428

Sivasubramanian K, Ravichandran S, Rameshkumar G, Allayie SA (2011) Infestation of Exocoetus volitans (Linnaeus, 1758), a new host of Nerocila exocoeti (Crustacea, Isopoda, Cymothoidae). Sci Parasitol 12:99-101

Trilles JP (1964) Parasitic specificity in the Mediterranean isopod Cymothoidae: preliminary note. Vie Milieu 15:105-116

Trilles JP (1972) Sur quatre isopodes cymothoidés du Pacifique (Nouvelle Calédonie). Cah O.R.S.T.O.M. Océanogr Fr 10:317

Trilles JP (1975) Les Cymothoidae (Isopoda, Flabellifera) des cotes francaises. II. Les Anilocridae Schioedte et Meinert, 1881. Genres Anilocra Leach, 1818, et Nerocila Leach, 1818. Bull Mus natn Hist nat, Paris 3e serie 290(Zoologie 200):347-378

Trilles JP (1979) Les Cymothoidae (Isopoda, Flabellifera; parasites des poissons) du Rijksmuseum van Natuurlijke Historiee de Leiden. II. Afrique, Amerique et regions Indo-Ouest-Pacifique. Zool Meded Leiden 54:245-275
Trilles JP (1994) Les Cymothoidae (Crustacea, Isopoda) du Monde. Prodrome pour une Faune. Stud Mar 21/22(1991):1-288

Trilles JP, Öktener (2004) Livoneca sinuata (Crustacea, Isopoda, Cymothoidae) on Loligo vulgaris from Turkey, and unusual cymothoid associations. Dis Aquat Org 61:235-240

Trilles JP, Ravichandran S, Rameshkumar G (2011) A checklist of the Cymothoidae (Crustacea, Isopoda) recorded from Indian fishes. Acta Parasitol 56:446-459

Tsai ML, Li JJ, Dai CF (1999) Why selection favors protandrous sex change for the parasitic isopod, Ichthyoxenus fushanensis (Isopoda: Cymothoidae). Evol Ecol 13:327-338

Veerapan N, Ramanathan M (1997) Report on some ectoparasitic isopods from the marine fish, Amblygaster sirm. J Environ Biol 18:351-356

Veerappan N, Ravichandran S (2000) Isopod parasites from marine fishes of Parangipettai coast. Centre of Advanced study in Marine Biology, Annamalai University, Parangipettai: $24 \mathrm{pp}$

Williams EH Jr, Williams LB (1980) Four species of Renocila (Isopoda: Cymothoidae), the first reported from the new world. Proc Biol Soc Wash 93:573-592

Williams EH Jr, Williams LB (1981) Nine new species of Anilocra (Crustacea: Isopoda: Cymothoidae) external parasites of West Indian coral reef fishes. Proc Biol Soc Wash 94:1005-1047

Wunderlich AC, Hattori GY, Trilles JP (2011) A new host record, Palaemonetes carteri (Gordon, 1935) (Decapoda, Palaemonidae), for Telotha henselii (Von Martens, 1869) (Isopoda, Cymothoidae). Crustaceana 84:1403-1409 